\title{
Evaluation of logging impacts on tropical rainforest in Eastern Cameroon using Remote Sensing and GIS techniques
}

\author{
Jules R. NGUEGUIM ${ }^{1 *}$, Hilaire CHOKONA GATCHUI ${ }^{2}$, Salami T. AYOBAMI ${ }^{3}$ \\ and O. O. ORIMOOGUNJE ${ }^{4}$ \\ ${ }^{1}$ Institute of Agricultural Research for Development. PoBox 219 Kribi, Cameroun. \\ ${ }^{2}$ Centre for the Promotion of Sustainable Development (CPSD), Environment Protection \\ Program, Yaoundé, Cameroon. \\ ${ }^{3}$ Space Applications and Environmental Science Laboratory, Institute of Ecology and \\ Environmental Studies, Obafemi Awolowo University, Ile-Ife, Nigeria. \\ ${ }^{4}$ Department of Geography, Obafemi Awolowo University, Ile-Ife. \\ *Corresponding author, Email: njules_romain@hotmail.com; Tel: 00 23777759062
}

\begin{abstract}
Various strategies and techniques have been designed and implemented to study the effects of logging activities on tropical rainforest amongst which remote sensing and GIS analysis. But there are still few measures available on the effects of industrial timber on forest ecosystem. This paper examined the impact of logging activities on tropical rainforest in Eastern Cameroon with the objectives of demonstrating the process whereby tropical rainforest got transformed into forest fragmentation and canopy damage. The study made use of data generated from Landsat TM (1986) and Landsat ETM + (2000). The satellites images covering the area were analysed using the Maximum Likelihood algorithm. The observed changes were mapped and the results of the classification were prepared as different theme in a GIS software. The classification results reveal a canopy damage of $10.8 \%$, the construction of $109.224 \mathrm{~km}$ of road and the fragmentation of forest into 18 parts. (c) 2009 International Formulae Group. All rights reserved.
\end{abstract}

Keywords: Forest Management Unit (FMU), Remote sensing, GIS, logging impact, logging road, forest fragmentation.

\section{INTRODUCTION}

In recent years, forest ecosystems have come under increasing pressure from human activities and environmental changes such as global deforestation for timbers exploitation, industrial plantation, warming and the impacts of pollution (Malingreau and Tucker, 1988). In 2005, the total forest area of the world was estimated at 3952 million hectares or 30 percent of its total land area (FAO, 2005a). Among these, we have the tropical rainforests (Amazon basin, and Congo basin rainforest) which constitute the most valuable ecosystems of the world, covering more than sixty countries and, containing 50 to $90 \%$ of animal and vegetal species on earth (CIDA, 2001; Kuntz et al., 1999; Mertens, 1999). They represent over $57 \%$ of global forest cover and are home to over 500 million people who live in or at the edges, depending on its products for their economic needs, for food, shelter, their cultural and spiritual traditions (CIDA, 2001; Talkington, 2001) as well as their medication (Chokona, 2000; Ngueguim, 2000). Central and West Africa's 200 millions hectares of contiguous tropical rainforest are the second largest remaining humid tropical forest in the world after the Amazon basin rainforest (Mertens, 1999; GFW, 2005). During the 1970s through 1990s, tropical 
deforestation rates were far greater than in any time in recorded history (Williams, 1989; Houghton et al., 2000), and despite the overall progress towards sustainable forest management in the world, Africa appears to have during the last fifteen years, the largest continued rapid loss of forest area (FAO, 2005b). In fact, all analysts agree that the planet is indeed losing forest cover. Forest loss has been estimated to be between 50,000 and 170,000 square kilometers per year (FAO, 1981; Lanly, 1982 ; Myers, 1991; Houghton, 1991; FAO, 1993), amongst which 6 million hectares of Primary forests are lost or modified each year (FAO, 2005a).

About 22.8 million hectares of the 200 million hectares of the Congo basin tropical rainforest vegetation is found in Cameroon. This forest is home of some 1661 known species of amphibians, birds, mammals and reptiles of which, $6.7 \%$ are threatened and $7.2 \%$ are endemic. It also contains about 8260 species of vascular plants, of which $1.9 \%$ are endemic (Mongabay, 2006). Despite the fact that Cameroon contains some of Africa's most biologically diverse and most threatened animals and forests species, only about 6 percent or 1.4 million hectares of Cameroon's forests are protected as national parks or reserves with 76 percent of the forests either being logged or are allocated as logging concessions. Therefore, less than a fifth of the country's unprotected forests, remain free from logging (MINFOF, 2004; GFW, 2005).

The annual rate of deforestation in Cameroon was estimated by FAO (1992) at about $0.6 \%$, corresponding to 122,000 hectares per year. Between 2000 and 2005, the rate of forest change increased to $0.98 \%$ per annum. This rate of deforestation contributes up to $4 \%$ of the total area deforested in the world. Between 1990 and 2005, Cameroon lost $13.4 \%$ of its forest cover, equivalent to 3,300,000 hectares (Mongabay, 2006). In addition, the estimated loss in biodiversity concerns about $2 \%$ of the total number of species each year (Eba'a Atyi, 2000).

The value and importance of the tropical rainforest to different people is as varied as the diverse goods and functions it provides (Ngueguim, 2000; Sonne, 2001). These functions are mainly productive, protective, and socio-economic (FAO, 2005b). Wood production continues to be an important function of many forests and one-third of the world's forests are used primarily for production of wood and non-wood forest products (FAO, 2005b). This is also the case in Cameroon where different types of permits granting logging rights can be found. Exploitation permits and autorisation de récupération which are short-term volumebased logging titles reserved for nationals; Ventes de Coupe are 2,500-hectare permits allocated for 1- 3 years; Forest Management Unit (FMU), are large long-term titles; and Community forests are forest blocks of up to 5,000 hectares whose management is entrusted to local communities, with benefits accruing to them (MINEF, 1994). According to WRI (2002), Cameroon is one of the world's top five tropical timber exporting countries. The country's timber exports are worth and estimated $\$ 230 \mathrm{~m}$ per year (Bikié et al., 2000).

Recent research has indicated that computer-simulation models driven by remotely sensed estimates of key variables may be used to assess the spatial impact of global environment changes on forest processes (Neils et al., 1999; Nightingale, 2004; Ranson, 1988). Neils et al. (1999) outlines an investigation that examined whether a general ecosystem simulation model (FOREST-BGC), driven by remotely sensed and meteorological data, could be used to estimate forest processes for a Sitka spruce (Picea sitchensis) plantation in mid-Wales. The purpose of this study is to quantify the impacts of 16 years of logging activities on FMU 10-054 in eastern Cameroon using Remote Sensing \& GIS techniques. This was done by examining the actual land cover before and after timber extraction; identifying the nature of road network system and its impact; estimating the total forest area cleared off for road construction and leading to forest fragmentation.

\section{MATERIALS AND METHODS \\ Study area}

The area of study is located in the East province of Cameroon. Geographically, it is located between latitude $3^{\circ} 45^{\prime}-4^{\circ} 15^{\prime}$ north and longitude $13^{\circ} 45^{\prime}-14^{\circ} 15^{\prime}$ east. In UTM coordinate, it is located in UTM WGS 84 North Zone 33. It covers a surface area of 67500.107 ha and bounded at the north by 
FMU 10-056, at the south by FMU 10-038, at the east by FMU 10-053, and at the west by FMU 10-055. Logging activities were carried out by Forestry and Industrial Society of Doumé SFID ("Société Forestière et Idustrielle de Doumé”) (GFW, 2005).

The climate is equatorial and humid. Average annual rainfall is $1600 \mathrm{~mm}$, while annual temperature is $23{ }^{\circ} \mathrm{C}$. The FMU $10-054$ is situated in the Congo basin on the Precambrian plateau. The altitude of this plateau varies between 600 and $700 \mathrm{~m}$ and slopes slightly towards the southeast. Relief is characterized by shallow valleys (Bedel et al., 1987). This FMU belongs to the evergreen Cameroonian-Congolese forest. According to Sonké (1998), three broad categories of forests can be distinguished in the region: forests on rocks, forests on firm soil and aquatic or hydromorphic forests. A large proportion of the equatorial wildlife and flora can be found in this area (Figure 1).

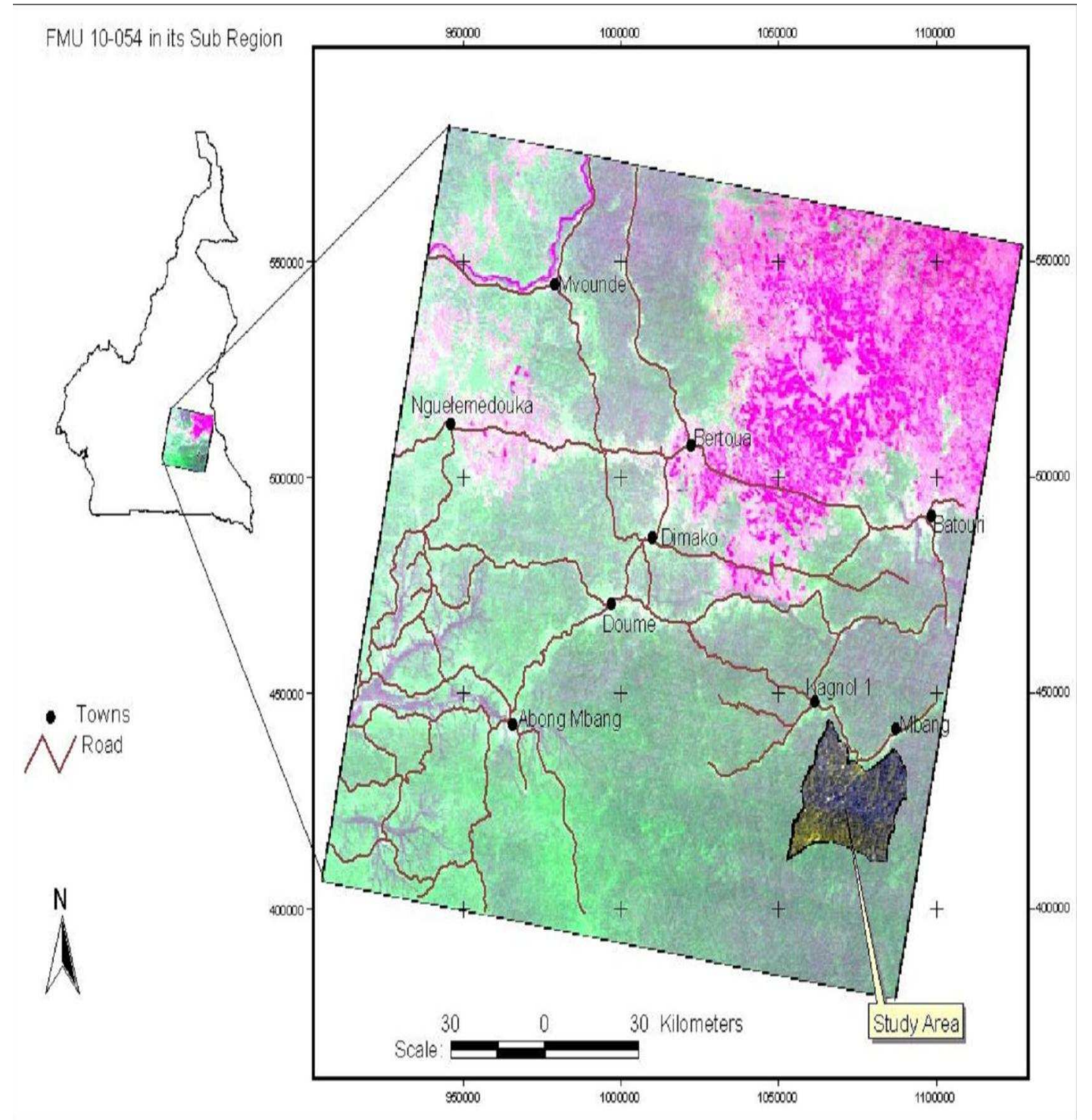

Figure1: Map of the study area. 


\section{Method}

This research used GIS and Remote Sensing techniques. The advent of GIS and Remote Sensing offers greater possibilities for land cover mapping and is described by many researchers as a new and the most useful tools for quantitatively measuring land cover change at landscape scale (Lunettaa et al., 2002; Pandey, 2000; Petit et al., 2001). An overview of recent satellite spectral sensors and the methods used to retrieve remotely quantitative biophysical and biochemical characteristics of vegetation canopies shows that there have been substantial advances in optical remote sensing over the past few decades. Nevertheless, adaptation and transfer of currently available fluorometric methods aboard air- and space-borne platforms can help to eliminate errors and uncertainties in recent remote sensing data interpretation (Zbynek et al., 2009). In recent years, forest fire has become a national disaster for Malaysia because of its impact on biodiversity, landscape, health and economic losses. The study has developed a model using the integration of remote sensing and GIS to produce Fire Risk Index (FRI) maps which could be modified interactively with changing weather conditions. Due to the success of Remote Sensing and GIS tools in forestry and land cover change detection elsewhere, its use was interesting in this research. The activities carried out during this research include: satellite image interpretation for land cover mapping, qualitative description of land cover classes and analysis of land cover change.

To identify the impact of logging activities, two Landsat images were used. The first one of 1986 from Landsat TM and the second one of 2000 from Landsat (ETM+) both of them of $28.5 \mathrm{~m}$ spatial resolution orthorectified. The images used were a P184 R57 of November year 1986 and a P184 R57 of 2000. The FMU shape file was retrieved from the Cameroon Forestry Atlas of 2004. To process the images, ERDAS IMAGINE 8.5 and ArcView GIS 3.2a software were used.

\section{Land cover mapping}

Land cover mapping aimed at realising land cover maps for the years 1986 and 2000 with the same level of generalisation. Land cover mapping was achieved through interpretation and classification of Landsat TM satellite images of 1986 and 2000. The maps of two different years were important for the analysis of land cover change in the FMU.

\section{Satellite image processing}

The two Landsat images were georeferenced to the coordinates system of the study area (WGS84, projection: UTM zone $33)$. For visual interpretation, different band combination were performed (4-4-3; 4-3-2; 57-4), satellite images were enhanced through the use of Contrast Tool, Smooth, Sharpen and Convolution Filtering in ERDAS IMAGINE software. Also, a supervised image classification was carried out for land cover maps of 1986 and 2000 using ERDAS IMAGINE 8.5 version. Onscreen digitisation was needed for feature extraction and overlay. For this task, Arc View GIS 3.2a and ERDAS IMAGINE 8.5 were used.

\section{Land cover change detection, qualification and quantification}

The objective of analyzing the spatiotemporal dynamics of the land cover was to monitor the changes of the tropical rainforest vegetation cover of FMU 10-054. This was based on post classification comparison of independently classified land cover maps of 1986, and 2000. The technique used for change detection and forest fragmentation was GIS overlay in ArcView. In this technique, the output table from the overlay of maps of the different dates was used to qualify and quantify the land cover changes. Land cover changes were investigated for the periods 1986-2000.

\section{Logging road breadth estimation}

Estimation of logging road width (W) was done by counting the number of adjacent pixels $(\mathrm{N})$ having the same reflectance and representing the road and by multiplying by the spatial resolution $X$ (28.5) of the satellite image.

$$
\mathrm{W}=\mathrm{N} * \mathrm{X}
$$

\section{RESULTS}

\section{Land cover mapping}

Image from meteorological satellite NOAA, can be used to study at large scale seasonal variation of vegetation over the world and to survey forest degradation. This experience been done to monitor fire in Amazonian forest and riziculture in Asiatic plantation. Image from Landsat 5 and Spotl help to identify, map and study small details 
in a forest ecosystem (Gourmelon et al., 2004). Based on spectral characteristics of satellite images, two land cover classes were discriminated on the image of 1986 while four land cover classes were identified on the image of 2000 (Figure 2). These included: Hydromorphic Forest (HF) and Firm Soil Forest (FSF) for the first image and HF, FSF, Settlement/Bare Soil and Shrub/logging road for the second image. It is important to note the presence of bands of noise on the 1986 image. As a consequence, it increases the area of HF on the concerned image. Zbynek et al. (2009) reviewed red and blue-green fluorescence emission as measured in the laboratory and field; he realized that, remotely sensed plant fluorescence signals have the potential to facilitate a better understanding of vegetation photosynthetic dynamics and primary production on a large scale. His study summarizes several scientific challenges that still need to be resolved to achieve operational fluorescence based remote sensing approaches.

There were no presence of settlement, shrub and logging road. Thus, in 1986 the forest area was almost in the original state; this means the area had not been much disturbed by human occupation. This can be explain by the fact that the population at that particular point was manageable, either there were not many people who probably knew about the opening up of the forest reserve to intruders, or the stricter control of the forest reserve by government agencies.

Table 1 shows that in 2000, the percentage of all the land cover identified in 1986 have reduced due to human activities especially logging road construction and settlements, this is illustrated in figure 3 where the area coverage of different land use classes in 1986 and 2000 clearly showed land -use pattern.

\section{Patterns of land use changes}

Land cover change analysis for the periods 1986-2000 (Figure 2 and 3) revealed the presence of two new land use Classes: Settlement/Bare Soil and Shrub/Logging Road. The first class are area which can never be colonised by forest vegetation (1242.64 ha) while on the second class (5504.5424 ha), forest vegetation can be expected after a long period of time. The results further revealed a lost of 6626.29 ha of Firm Soil Forest (FSF) class representing $12.28 \%$ of Firm Soil Forest lost and a $9.79 \%$ of the total forest area. It should be noted that a decrease of 683.89 ha of forest which represents almost $5 \%$ of the $\mathrm{HF}$, and $1.01 \%$ of the total forest was observed (Table 2 and figure 4). From these results, it could be estimated that the total forest lost due to commercial timber extraction was 6747.1824 ha which represent $10.80 \%$ of the concerned FMU surface, and a forest lost rate due to industrial logging of $0.77 \%$ per year (regardless the cloud covered area which represents $0.82 \%$ of the area). With anthropogenic pressures, several hectares of forests disappear every year in Ivory Coast, particularly in National Park. This degradation of forest cover creates the biodiversity decrease (Chevalier, 1998; CI and MINEFOR, 2001). For a best understanding of forest disappearance phenomenon in the protected areas, Dibi N'da et al. (2008) characterized and mapped the plant cover of Marahoué National Park and valued the forest dynamics from 1986 to 2003 by spatial imagery. Landsat images ETM+ of 2003 and TM of 1986 where used (Defourny, 1990). Thus, ETM4-5-3 and ACP1-2-3 colour composites with the best discrimination of land use helped to collect land data on vegetation and flora from 100 test-sites. The maximum likelihood classification method on satellite images permitted to map Marahoué Park vegetation of 1986 and 2003. Thus, it was possible to discriminate forests, savannas and cultures with various accuracies. Indeed, spectral confusion between two neighboring classes is related to the structure (basal area) of the woody layers in forest formations. This interrelationship does not exist in formations with lower tree densities. From 1986 to 2003 (17 years), 16378 hectares $(21,70 \%)$ of forests disappeared with the agricultural activities. This deforestation is more important in the West South (Bonon), where the demographic growth was the strongest (58\%) from 1988 to 1998. The forest of the Marahoué National Park will disappear very soon with agricultural activities if no management plan is applied. 
J. R. NGUEGUIM et al. / Int. J. Biol. Chem. Sci. 3(4): 771-785, 2009

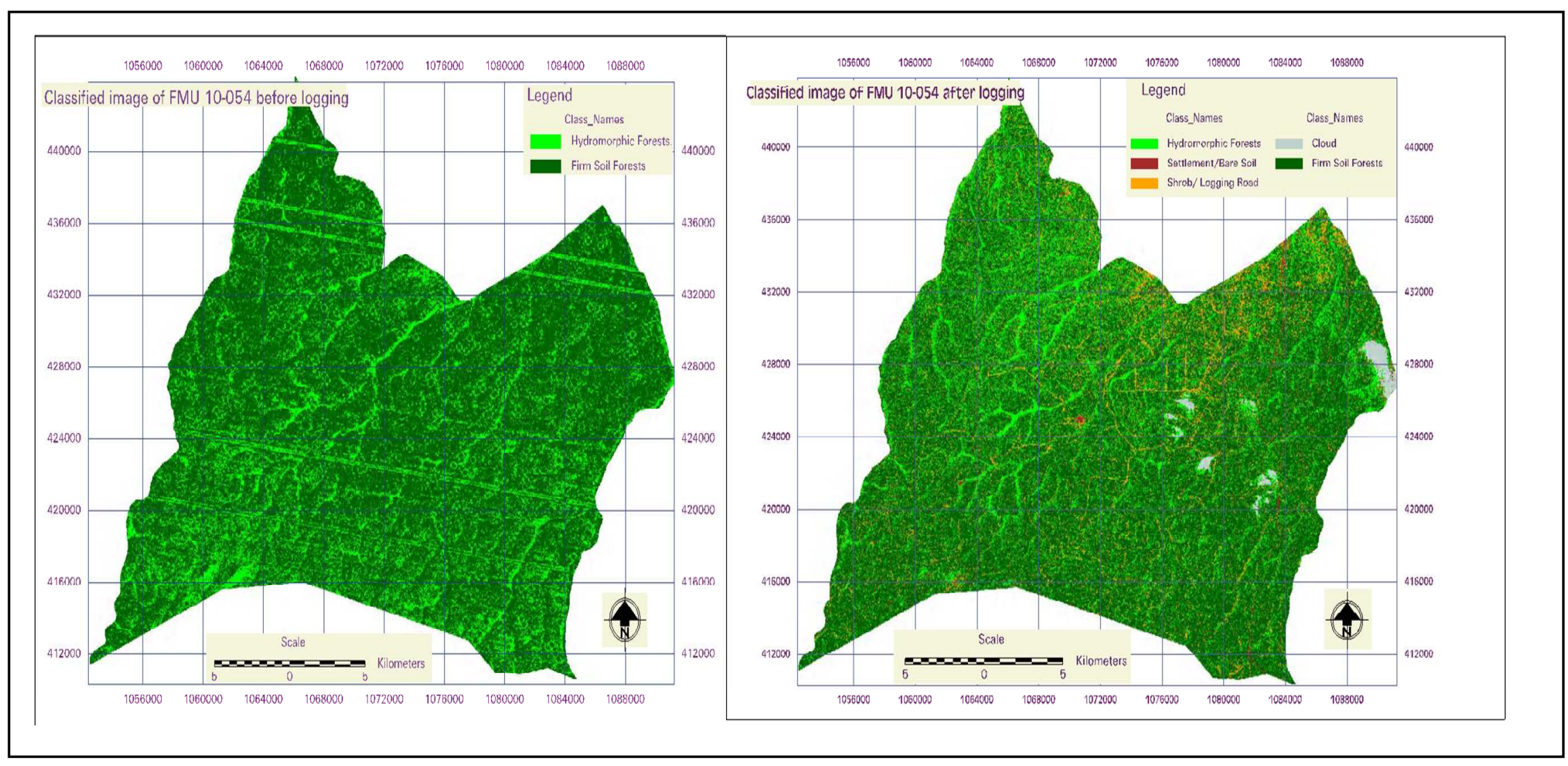

Figure 2: Classified image of FMU 10-054 in1986 (left) and 2000 (right). 
Table 1: Size of land cover / land use classes between 1986 and 2000.

\begin{tabular}{lcccc}
\hline \multirow{2}{*}{ Classes } & \multicolumn{2}{c}{ Area (ha) } & \multicolumn{2}{c}{ percentage } \\
\cline { 2 - 5 } & $\mathbf{1 9 8 6}$ & $\mathbf{2 0 0 0}$ & $\mathbf{1 9 8 6}$ & $\mathbf{2 0 0 0}$ \\
\hline Hydromorphic Forests & 13698.832 & 13014.9488 & 20.25 & 19.24 \\
Settlement/Bare Soil & & 1242.64 & & 1.836455 \\
Shrub/ Logging Road & & 5504.5424 & & 8.134973 \\
Cloud & & 559.619 & & 0.827042 \\
Firm Soil Forests & 53969.6976 & 47343.408 & 79.75 & 69.96719 \\
\hline
\end{tabular}

Table 2: Land Used Land Cover changes evolution 1986 and 2000.

\begin{tabular}{lccc}
\hline Classes & $\begin{array}{c}\text { Area (ha) in 1986 } \\
\text { (before logging) }\end{array}$ & $\begin{array}{c}\text { Area(ha) in 2000 } \\
\text { (after logging) }\end{array}$ & $\begin{array}{c}\text { Class Change in } \\
\text { Area (ha) }\end{array}$ \\
\hline Hydromorphic Forests & 13698.832 & 13014.9488 & -683.8832 \\
Settlement/Bare Soil & 0 & 1242.64 & +1242.64 \\
Shrub/ Logging Road & 0 & 5504.5424 & +5504.5424 \\
Cloud & 0 & 559.619 & 559.619 \\
Firm Soil Forests & 53969.6976 & 47343.408 & -6626.2896
\end{tabular}

The minus (-) in front of a class change means a lost of area in the concerned class, and the plus (+) means a gain of area in the class concerned.

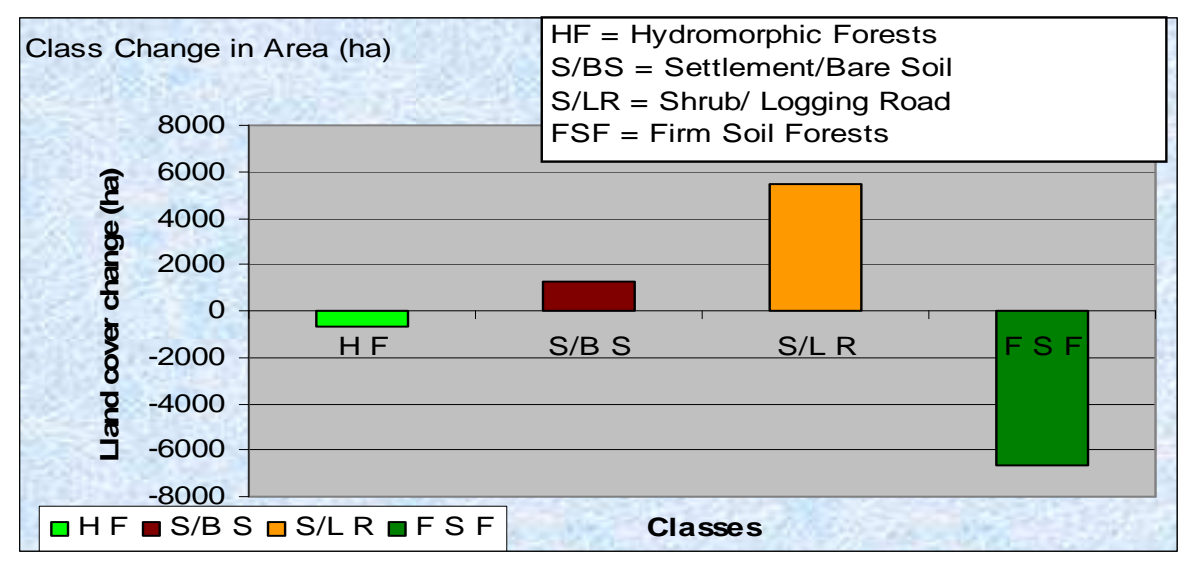

Figure 4: Land use/ land cover changes between 1986 and 2000

\section{Logging road impact}

A total of $109.224 \mathrm{~km}$ logging road representing an average of $17 \mathrm{~m}$ of road per ha was opened up for timber extraction (Figure $5)$.

Road breadth on the image varies from 0 to 3 pixel width and often 4 in some part of the same piece of road. This in term of meters gives 28.5 to $57 \mathrm{~m}$ for the most often and even $85.5 \mathrm{~m}$ (Figure 6)

\section{Forest fragmentation}

The aftermath of road construction logging and timber extraction, is forest fragmentation. The FMU has been split into 18 fragments (Figure 7), where the smallest fragment is $1.707 \mathrm{ha}$, the largest fragment is 1946.900 ha (Table 3) and an average forest fragment size of 348.46 ha. Forest fragmentation has as consequence habitat fragmentation, thus affecting the live of wildlife. 
J. R. NGUEGUIM et al. / Int. J. Biol. Chem. Sci. 3(4): 771-785, 2009

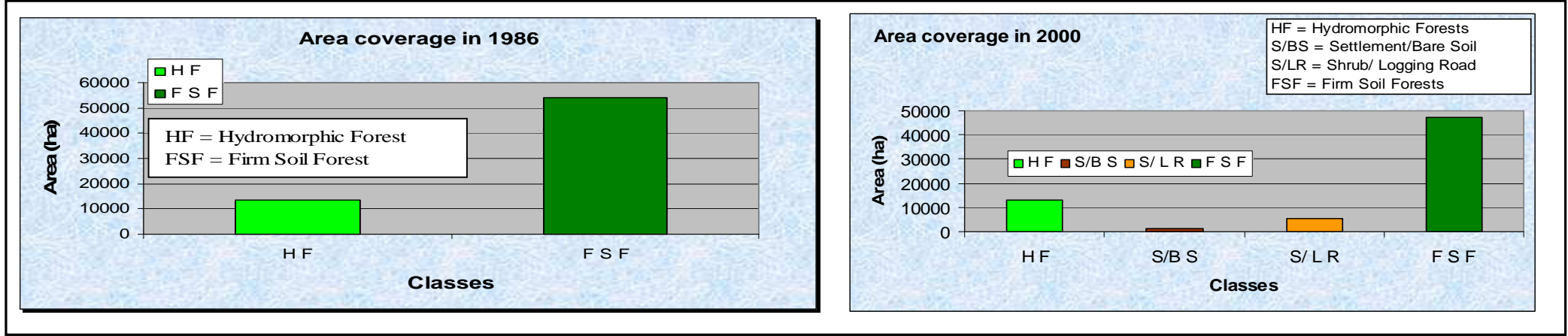

Figure 3: Area coverage of different Land Cover classes in 1986 (left) and 2000 (right)

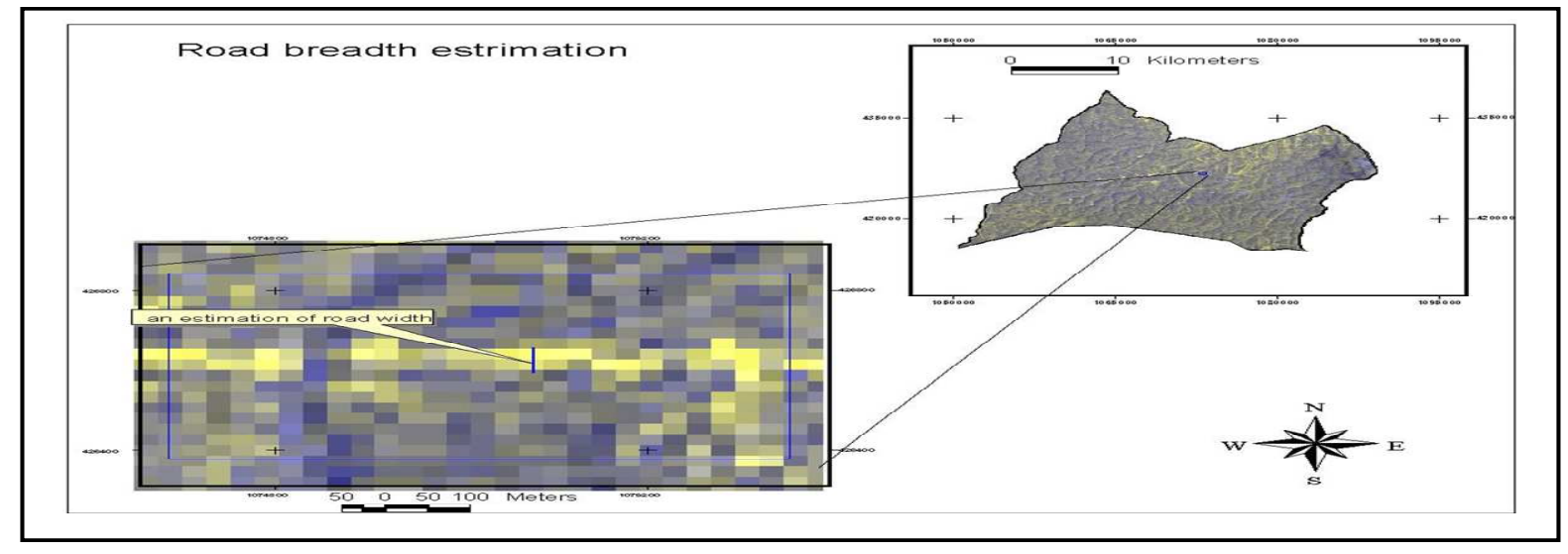

Figure 6: Road width estimation.

778 


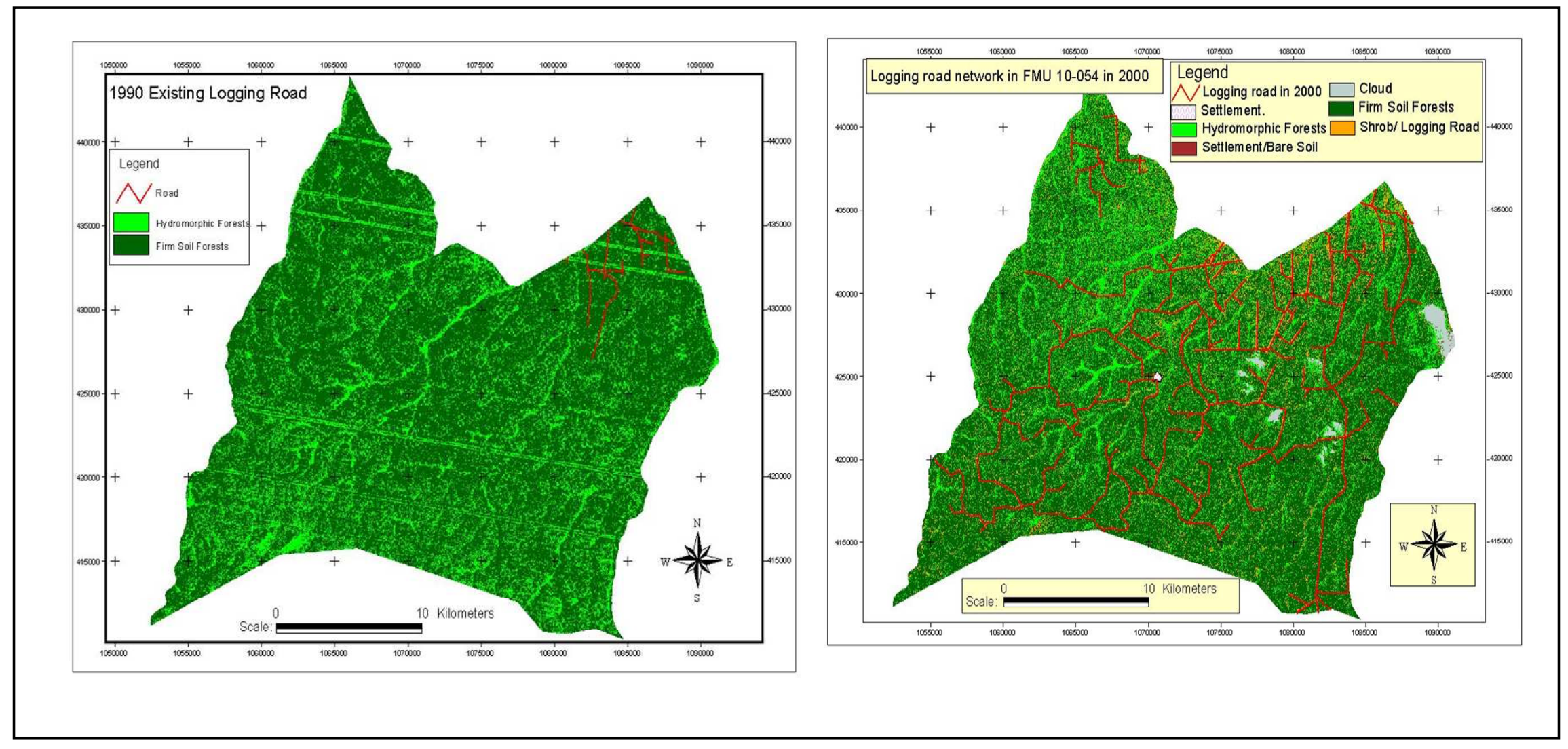

Figure 5: Road network for 1986 (left) and 2002 (right) for the whole study area. 


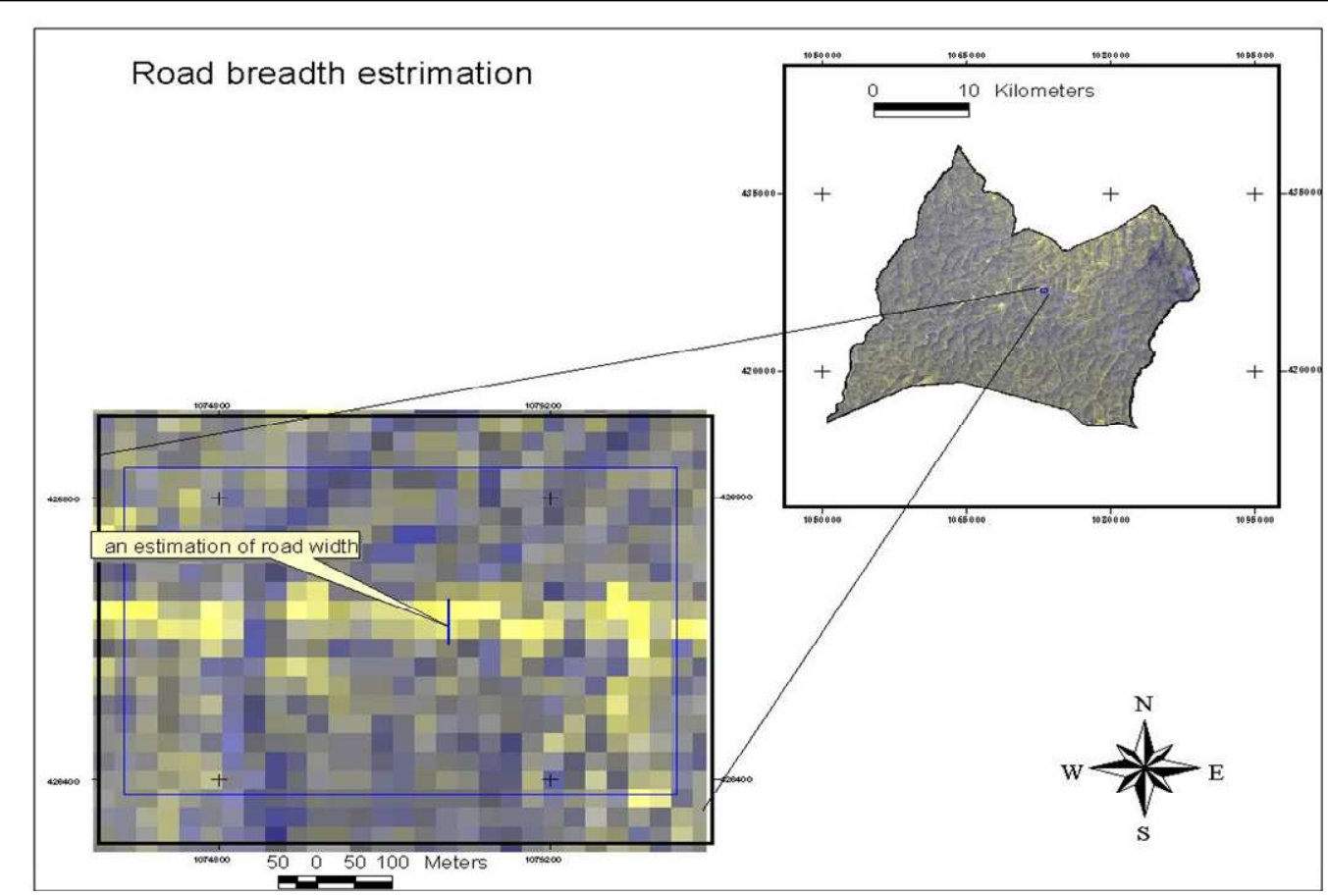

Figure 6: Road width estimation.
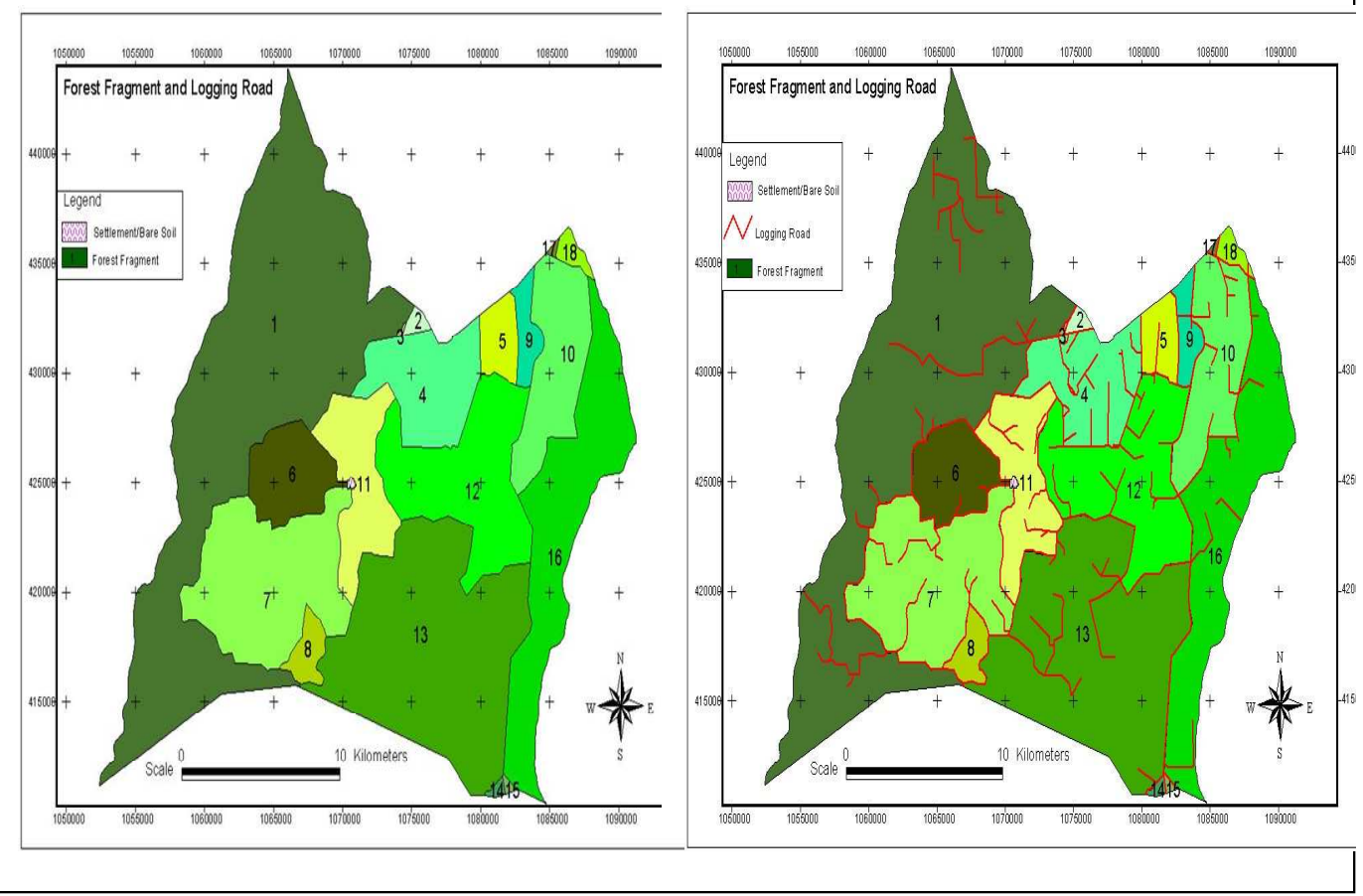

Figure 7: Forest fragmentation due to logging activities (left) and the residual forest in 2000. 
Table 3: Area of different forest fragment.

\begin{tabular}{lccccc}
\hline $\mathbf{N}^{\mathbf{0}}$ & Area (ha) & $\mathbf{N}^{\mathbf{0}}$ & Area (ha) & $\mathbf{N}^{\mathbf{0}}$ & Area (ha) \\
\hline 1 & 1946.900 & 7 & 618.133 & 13 & 1115.924 \\
2 & 14.032 & 8 & 58.771 & 14 & 6.697 \\
3 & 1.707 & 9 & 64.093 & 15 & 3.988 \\
4 & 319.237 & 10 & 328.299 & 16 & 645.137 \\
5 & 85.874 & 11 & 286.329 & 17 & 3.498 \\
6 & 212.125 & 12 & 535.075 & 18 & 26.520 \\
\hline
\end{tabular}

\section{DISCUSSION}

Road construction is a necessary operation for industrial timber extraction. The estimation of road wide was not easy, the variation in pixel number covering the road breadth can be explained by the fact that, crown cover along the road can varied. A review of studies carried in tropical rainforest by Haworth in 1999 revealed a total length of roads in the unplanned extraction as $27.3 \mathrm{~m} / \mathrm{ha}$ (with a corridor of damage of $12.3 \mathrm{~m}$ wide) compared to $22.6 \mathrm{~m} / \mathrm{ha}$ (with a corridor of damage of $9.0 \mathrm{~m}$ ) for RIL. The result of 17 $\mathrm{m} / \mathrm{ha}$ found in this study is less than the one of Haworth (1999), but is above the average of 5 to $10 \mathrm{~m}$ found by Durrieu et al. (1998) in rain forest in Cameroon. This means that if the parameter of meter of road opened per hectare of forest is taken as witness, it could be inferred that a RIL was applied in accordance with the findings of Haworth (1999). But paradoxally, according to the result of Durrieu de Madron et al. (1998) who worked in the same ecosystem as one of this study, and taking into consideration the result of road wide found by Johns et al. (1996), it could be said that the forest was not sustainably exploited. According to Durrieu de Madron et al. (1998) after a study carried in rain forest in Cameroon, the primary roads and secondary roads represent in general 1 to $2 \%$ of the disturbed area of the forest. Esteve (1990) quoted a general average of $30 \mathrm{~m}$ wide of forest destroyed for road during the first timber harvesting, while Maître (1990) quoted 30 to $45 \mathrm{~m}$ wide, which is not far from the result of 28.5 to 57 found in this study.

The results of studies carried out by API project (Pilot Management Integrated) in the semi deciduous forest of Cameroon exploited for the second or third time revealed the mean wide of primary road to $16.7 \mathrm{~m}$ while the secondary road width is estimated at $8 \mathrm{~m}$, with $1.7 \%$ of the surface cover by primary roads (Durrieu et al., 1998).

These results are different from the one obtained in this study where $10.80 \%$ of canopy opened due to wood extraction was observed. This difference can be explained by the fact that this study estimated the total land cover change, and not only the one covered by the primary roads. The result obtained in this study is also in line with those of White (1994). In Gabon, Lasserre and Gautier-Hion found that the percentages of canopy opened varied between $10.2 \%$ and $14 \%$ (Haworth, 1999). Abdelkrim et al. (2002) studied the vegetation of Aflou city, a steppe region confronted with land degradation problems which is known for its ancestral pastoral activity. According to the National Agency of Territory Management, there is a high pressure on land pasture when there is more than 0.25 cattle per ha, with a risk of degradation on the vegetation; on the contrary there is no risk (Boukhobza, 1982; Smahi, 1997). In view of the complexity of the region and the problem to address, a methodology based on powerful tools such as GIS and remote sensing was designed. They produced a land use map which includes a characterization of the various grazing paths of the region, based on an analysis of Landsat imagery, as well as of land cover maps and change maps spanning a 19 years period (1976-1995), which were obtained from Landsat TM and MSS imagery. The results and other data relevant to the study area were integrated in a GIS, as a starting point for their SIG-STEPPE application for grass resources management. The application is conceived based on the principle of double-prototyping method. Within the application they designed a functionality that allow producing a map of 
grazing path degradation at the commune level and combined physical data (such as surface and condition of grazing paths) and socio-economic data (number of herds per commune) to compute a "carrying capacity index". This index, which is expressed as the ratio between the number of herds and the surface of corresponding grazing paths, is believed to be the best way to estimate grazing pressure on the grazing paths. This study reveals the regression of vegetation land cover during the years 1976 to 1995 and notice an amelioration of land cover in 1995 comparing to 1986 in Aflou region. The increasing of deforestation area, tropical savanna and desertification are probably interdependent transformation which need to be jointly studied (Blasco and Achard, 1990; Achard, 1989). According to Bennouna et al. (1995), the risk of desertification appears when anthropogenic activities considerably modify the ecosystem more than the limit of resistance.

\section{Conclusion}

This study was seeking to survey the impacts of logging activities on tropical rain forest in eastern Cameroon using Remote Sensing \& GIS techniques. Detection of changes due to deforestation and assessment of width and length of created logging roads, as well as forest fragmentation, and canopy damage in forest was exanimate on two Landsat images of different years (1986; 2000).

A total of $109.224 \mathrm{~km}$ logging road was opened for timber extraction in the 67500.107 ha of forest, representing an average of $17 \mathrm{~m}$ of road opened per ha. On the image of 2000 due to logging activities, two new land use classes known as Settlement/Bare Soil and Shrub/logging road appear with a surface area of 1242.64 ha and 5504.5424 ha respectively. Further the study revealed a lost of 6626.29 ha of Firm Soil Forest (FSF) representing $12.28 \%$ of original FSF and $9.79 \%$ of the total FMU. A decrease of 683.89 ha of forest that is almost $5 \%$ of the HF and $1.01 \%$ of the total forest was observed. In total, forest lost due to commercial timber extraction was estimated at 6747.1824 ha which represent $10.80 \%$ of the area of the concerned FMU, and a forest lost rate of $0.77 \%$ per year.
The availability and use of time series satellite images permitted the detection and quantification of land cover dynamics in the study area. This has been useful in improving our understanding of the impact of industrial timber extraction on tropical rainforest.

\section{ACKNOWLEDGMENTS}

The research reported here has been possible due to the support of the African Regional Centre for Space Science and Technology Education in English, based in Awolowo University, Nigeria, in association with the Center for the Promotion of Sustainable Development, based in Yaoundé, Cameroon. The views here expressed are strictly those of the authors and do not necessarily reflect those of the sponsoring institutions.

\section{REFERENCES}

Abdelkrim B, Zakaria S, Tahar I, Said B. 2003. The use of remote sensing and GIS for the assistance and monitoring the Algerian steppe degradation risk. Télédétection, 3(5): 387-402.

Achard F. 1989. Étude des rythmes saisonniers de la végétation en Afrique de l'Ouest par télédétection spatiale. Thèse de doctorat de I'Université Paul-Sabatier de Toulouse, 246p.

Boukhobza M. 1982. L'Agropastoralisme Traditionnel en Algérie. Office des Publications Universitaires : Alger ; 458p.

Bennouna A, Kaemmerer M, Manière R. Le Fevre M. 1995. Méthodologie de caractérisation des parcours subdésertiques (région de OuarzazateMaroc). Séminaire sur les systèmes d'information géographique pour la gestion durable des ressources naturelles en Afrique. AFRICAGIS, Abidjan, Côte d'Ivoire, 26p.

Bedel J, Bousquet B, Gourlet S. 1987. Réserve de biosphère du Dja. Report of the Government of Cameroon and UNESCO/MAB. Ecole Nationale du Génie Rural des Eaux et des Forêts, Montpellier, France, 96p.

Bikié H, Collomb JG, Djomo L, Minnemeyer S, Ngoufo R, Nguiffo S. 2000. An overview of logging in Cameroon, A Global Forest Watch Cameroon Report, WRI, 72. 
Blasco F, Achard F. 1990. Analysis of vegetation changes using satellite data. In Soils and the Greenhouse Effect, Bouwman AF (ed). John Wiley \& Sons, Inc.; 10p.

Chevalier JF. 1998. Évaluation de l'imagerie spatiale haute résolution pour la cartographie et le suivi du couvert végétal des aires protégées et leur zone périphérique: cas du Parc National de la Marahoué (Côte d'Ivoire), Mémoire de DEA, Université de Cocody, 63p.

Chomentowski WH. 2000. Annual fluxes of carbon from deforestation and regrowth in the Brazilian. Amazon. Nature, 403: 301-304.

CI (Conservation Internationale) et MINEFOR (Ministère des Eaux et Forêts). 2001. Ligne Directrices pour le Parc National de la Marahoué, République de Côte d'Ivoire, 91p.

Chokona GH. 2000. Contribution à l'étude des modes traditionnels de gestion des ressources naturelles $\mathrm{Au}$ nord du massif forestier de Lokoundjé-Nyong. Engineer Thesis, Department of Forestry, University of Dschang, 85p.

CIDA. 2001, Deforestation: tropical forests in decline. CIDA. Retrieved, 18.

Defourny P. (1990) Méthode d'évaluation quantitative de la végétation ligneuse en région soudano-sahélienne à partir de données Landsat TM (Burkina Faso). In Télédétection et Sècheresse. Ed. AUPELF-UREF ; 63-74

Deshayes, M. Indices satellitaux et stress hydrique de la végétation méditerranéenne: Du Bosquet au pixel. Laboratoire: UMR Cemagref-ENGREF Structures et Systèmes spatiaux. 11p.

Durieu de Madron L, Forny E, Mekok M. 1998. Les techniques d'exploitation à faible impact en forêt dense humide camerounaise. Série FORAFRI, Document 17, CIRAD Forêt, Montpellier, France.

Dibi N'da H, Kouakou EN, Egnankou MW, Kouadio A. 2008. Followed of the deforestation in Marahoué national Parc (Côte d'Ivoire) using remote sensing. Revue Télédétection, 8(1): 17-34

Eba'a Atyi R. 2000. A decision support model for sustainable management of SouthCameroon's rain forests. Tropenbos-
Cameroon Programme Series 2, Kribi, Cameroon. 203p.

Esteve MJ. 1990. Rational exploitation of forest products in dense African forest and the consequences of destruction and alteration of forest cover In Conservation of West and Central African Rainforests. Selected papers from a conference organized by the International Union for the Conservation of Nature (IUCN) and the World Bank (WB).

FAO. 1981. Tropical forest resources assessment project. Forest Resources of Tropical America. FAO, Rome, Italy, $342 \mathrm{p}$.

FAO. 1992. Forest resources assessment 1990: Tropical Countries. FAO Forestry Paper 112. Food and Agriculture Organization of the United Nations, Rome.

FAO. 1993. Forest resources assessment 1990. FAO Forestry Paper 112, Rome, Italy, 61p.

FAO. 2005a. Global Forest resources assessment 2005, Progress towards sustainable forest management, $348 \mathrm{pp}$. Retrieved Jun $18^{\text {th }} 2006$ from World Wide Web http://www.fao.org/ documents/show_cdr.asp?url_file

FAO. 2005b. State of word forest 2005, 104 pp. Retrieved Jun 18th 2006 from World Wide Web: http://www.fao.org/ documents/show_cdr.asp?url_file

GFW. 2005. Interactive Forestry Atlas of Cameroon, Version 1.0, An Overview, MINEF, GFW, WRI. Karen Holmes, United States of America, p.47.

Gourmelon F, Sauve L, Bioret F. 2004. Potentialités de l'imagerie satellitaire spot 5 pour la cartographie de la végétation terrestre application a l'ile d'Ouessant (Finistere). Séminaire de restitution du 5 octobre 2004, cnes-ifen, Paris.

Haworth J. 1999. Life after Logging: The Impacts of Commercial Timber Extraction in Tropical Rainforests, A review carried out for the Rainforest Foundation UK, Rettet den Regenwald, Friends of the Earth England, Wales and Northern Ireland, The Environmental Defense Fund, and Greenpeace International. 78p. Retrieved August 29, 2006 from World Wide Web: 
http://www.rainforestfoundationuk.org/fil es/Logging.pdf

Houghton RA, Skole DL, Nobre CA, Hackler JL, Lawrence KT, Houghton RA. 1991. Tropical deforestation and atmospheric carbon cycle. Climate Change, 19: 99118.

Johns JS, Barreto P, Uhl C. 1996. Logging damage during planned and unplanned logging operations in the eastern Amazon. Forest Ecology and Management, 89: 59-77.

Kuntz S, Siegert F. 1999. Monitoring of deforestation and land use in Indonesia with multitemporal ERS data. International Journal of Remote Sensing, 20(14): 2835-2853.

Lanly JP. 1982. Tropical forest resources. FAO Forestry Paper 30. FAO, Rome, Italy. $106 \mathrm{p}$.

Lunettaa RS, Ediriwickremab J, Johnsonb DM, Lyonc JG, McKerrowb A. 2002. Impacts of vegetation dynamics on the identification of land-cover change in a biologically complex community in North Carolina, USA. Remote Sensing of Environment, 82(2-3): 258-270.

Maitre HF. 1990. Recherches sur la Dynamique des Peuplements Arborés en Vue de définir une sylviculture assurant la Conservation et la Production Durable de l'écosystème Forestier Tropical Humide. In Conservation of West and Central African Rainforests. Selected Papers From a Conference Organized by the IUCN and the WB.

Malingreau JP, Tucker CJ. 1988. Large scale deforestation in the Southeastern Amazon Basin of Brasil. Ambio, 17(1): 49-55.

Mertens B. 1999. Spatial modeling of diverse deforestation processes. $\mathrm{PhD}$, Université Catholique de Louvain, Louvain.

MINEF. 1994. Loi $N^{\circ} 94 / 01$ du 20 janvier 1994 portant régime des forêts, de la faune et de la pêche.

MINFOF. 2004. ATLAS du Cameroun. L'accord entre WRI et le Ministère des Forêts et de la Faune du Cameroun restreint l'exploitation forestière illégale. Retrieved September 29 2006 from World Wide Web: http://www.minef.cm/ Home/Autres/Atlas\%20cameroun.htm
Myers N. 1991. Tropical forests: present status and future outlook. Climatic Change, 19: 3-32

Mongabay. 2006. Tropical Rain forest Statistic: Cameroon. Retrieved August $28^{\text {th }} 2006$ from World Wide Web http://rainforests.mongabay.com/deforest ation/2000/Cameroon.htm

Nightingale JM, Phinn SR, Held AA. 2004. Ecosystem process models at multiple scales for mapping tropical forest productivity. Progress in Physical Geography, 28(2): 241-281.

Neil SL, Curran PJ. 1999. Forest ecosystem simulation modelling: the role of remote sensing. Physical Geography, 23(3): 391423.

Ngueguim JR. 2000. Etude de la chasse villageoise dans l'Unité Technique Opérationnelle (UTO) Campo Ma'an. Mémoire d'Ingenieur, Université de Dschang, Projet Campo Ma'an, 87p.

Pandey VN. 2000. National forest cover assessment. Paper presented at the Biodiversity and Environment: Remote Sensing and Geographic Information System Perspective. Abidjan, Côte D'Ivoire. Environment Department and Africa Technical Department, the WB, Washington, D.C.

Petit C, Scudder T, Lambin EF. 2001. Quantifying processes of land cover change by Remote sensing: resettlement and rapid land cover changes in South Eastern Zambia. International Journal of Remote Sensing, 22(17): 3435-3456.

Ranson KJ, Smith JA, Hall FG. 1988. Characterizing forest ecosystem dynamics through modelling and remote sensing observations. Geoscience and Remote Sensing Symposium. IGARSS apos: 88. Remote Sensing: Moving Toward the 21st Century. International, 3: $1347-1350$.

Sonké B. 1998. Etudes floristiques et structurales des forêts de la réserve de faune du Dja (Cameroun). Thèse de doctorat, Univ. Libre de Bruxelles.

Sonne N. 2001. Non timber forest products in the Campo Ma'an Project area: A case study of the North eastern periphery of the Campo National Park, South Cameroon (Consultancy report): Campo Ma'an Project. 
Smahi Z. 1997. Intégration des données physiques et socioéconomiques dans un SIG pour la gestion pastorale dans une zone de la région steppique. Thèse d'agister, Centre National des Techniques Spatiales, Arzew, 87 p. + annexes.

Talkington J. 2001: Use of Remote Sensing in Forestry Applications, ES 771 Remote Sensing, Emporia State University. Retrieved August $4^{\text {th }} 2006$ from World Wide Web http://www.emporia.edu/ earthsci/student/talk2/forestry 1 text.htm

White LTJ. 1994. The effects of commercial mechanised selective logging on a transect in lowland rainforest in the Lopé
Reserve, Gabon. Journal of Tropical Ecology, 10: 313-322.

WRI (World Resource Institute). 2002. News Release: Report reveals threats to Cameroon's growing timber industry. Retrieved May 1st, 2009 from World Wide Web: http://archive.wri.org/ news.cfm?id=71

Zbynek Malenovsky, Kumud BM, Zemek F, Uwe RL, Nedbal, 2009. Scientific and technical challenges in remote sensing of plant canopy reflectance and fluorescence. Remote Sensing Laboratories, Department of Geography, University of Zürich, Winterthurerstrasse 190, 8057 Zürich, Switzerland. 